Principal Managerial Competence in Improving Teacher Performance in SD Negeri Sapugara, Brang Rea District, West Sumbawa Regency, Academic Year 2019/2020

\title{
Kompetensi Manajerial Kepala Sekolah dalam Meningkatkan Kinerja Guru di SD Negeri Sapugara Kecamatan Brang Rea Kabupaten Sumbawa Barat Tahun Pelajaran 2019/2020
}

\author{
Zainuddin, S.Pd.I
}

\section{email : zain.alhadj@gmail.com}

\author{
Kepala Sekolah di SD Negeri Sapugara Kab. Sumbawa Barat
}

\begin{abstract}
This PTS discusses the managerial competence of school principals in improving teacher performance at SD Negeri Sapugara, Brang Rea District, West Sumbawa Regency, motivated by the important role of the principal in improving teacher performance, implementing school quality and at the same time in improving the quality of learning management, because of the steps a school organization controlled by a principal. This study is intended to answer the problem of how the principal's leadership is viewed from managerial competence in improving teacher performance in SD Negeri Sapugara, Brang Rea District, West Sumbawa Regency. This type of research is qualitative research. Methods of data collection using interviews, observation and documentation. Data analysis using qualitative descriptive analysis.

The results show that in the context of managerial competence, the principal of SD Negeri is able to prepare school plans for various levels of planning, develop school organizations according to needs, lead schools in order to optimize school resources, have the right strategy to improve the performance of educational personnel. at his school. Creating a conducive school climate, providing advice to school residents, encouraging all teachers, and implementing interesting learning models. It is human nature, besides the advantages there are also disadvantages, namely the Principal of SD Negeri because of his too discipline, sometimes in certain situations he is active in filling the lesson hours which are actually a portion of the teacher concerned. This condition gives the impression that the principal's level of trust in teachers is lacking.
\end{abstract}

Keywords: Principal managerial, Teacher performance

Abstrak: PTS ini membahas kompetensi manajerial kepala sekolah dalam meningkatkan kinerja guru di SD Negeri Sapugara Kecamatan Brang Rea Kabupaten Sumbawa Barat, dilatarbelakangi oleh peran penting kepala sekolah dalam rangka meningkatkan kinerja guru,

$$
\text { 97|Edisi } 2 \text { No.2 Juli } 2020
$$


menerapkan kualitas sekolah dan sekaligus dalam manajemen peningkatan mutu pembelajaran, karena gerak langkah sebuah organisasi sekolah dikendalikan oleh seorang kepala sekolah. Studi ini dimaksudkan untuk menjawab permasalahan bagaimana kepemimpinan kepala sekolah ditinjau dari kompetensi manajerial dalam meningkatkan kinerja guru di SD Negeri Sapugara Kecamatan Brang Rea Kabupaten Sumbawa Barat. Jenis penelitian ini adalah penelitian kualitatif. Metode pengumpulan data menggunakan wawancara, observasi dan dokumentasi. Analisis data menggunakan analisis deskriptif kualitatif.

Hasil penelitian menunjukkan bahwa dalam konteksnya dengan kompetensi manajerial, kepala sekolah SD Negeri mampu menyusun perencanaan sekolah untuk berbagai tingkatan perencanaan, mengembangkan organisasi sekolah sesuai dengan kebutuhan, memimpin sekolah dalam rangka pendayagunaan sumber daya sekolah secara optimal, memiliki strategi yang tepat untuk meningkatkan kinerja tenaga kependidikan di sekolahnya. Menciptakan iklim sekolah yang kondusif, memberikan nasehat kepada warga sekolah, memberikan dorongan kepada seluruh guru, serta melaksanakan model pembelajaran yang menarik. Sudah menjadi sifat manusia, di samping kelebihan ada pula kekurangannya yaitu Kepala sekolah SD Negeri karena terlalu disiplinnya, terkadang dalam situasi tertentu aktif mengisi jam pelajaran yang sebetulnya menjadi porsi guru yang bersangkutan. Kondisi ini menimbulkan kesan kurangnya tingkat kepercayaan kepala sekolah terhadap guru.

Kata Kunci: Manajerial kepala sekolah, Kinerja guru

\section{A. Pendahuluan}

Kepala sekolah sebagai administrator memegang kunci bagi perbaikan dai kemajuan sekolah. Ia harus mampu memimpin dan menjalankan peranannya agar segala kegiatan terkendali dan terarah dalam usaha inovasi dan mencoba ide-ide baru dan praktek-praktek baru dalam bentuk manajemen kelas yang lebih efektif dan efisien. Kepala sekolah sebagai administrator pendidikan bertanggung jawab penuh dalam pelaksanaan pendidikan dan pengajaran di sekolahnya. Oleh karena itu untuk dapat melaksanakan tugasnya dengan baik, kepala sekolah hendaknya memahami, menguasai dan mampu melaksanakan kegiatan-kegiatan yang sesuai dengan fungsinya sebagai administrator pendidikan. Lebih jauh lagi dari manajemen kepemimpinan kepala sekolah diharapkan dapat meningkatkan kinerja para guru, siswa dan komponen pendidikan lainnya.

Kenyataan menunjukkan bahwa hasil penelitian Bank Dunia menemukan bahwa banyak kepala sekolah yang tidak memiliki kualifikasi memadai, baik kompetensi profesional maupun kemampuan manajerial terlebih lagi dalam

$$
\text { 98| Edisi } 2 \text { No.2 Juli } 2020
$$


dimensi kepemimpinannya. Keterangan ini menunjukkan penting dan menariknya masalah ini diteliti. Alasan menariknya adalah karena, salah satu sebabnya ketiadaan kualifikasi yang memadai bagi kepala sekolah adalah akibat kurang atau tidak memiliki otonomi dalam menjalankan sekolah terutama mengalokasikan sumber daya yang tersedia. Indikatornya, pertama, bersifat sentralistik yaitu segala sesuatu yang berkenaan dengan penyelenggaraan pendidikan diatur secara ketat oleh pemerintah pusat. Kedua, segalanya ditetapkan berdasarkan dari pusat sehingga tidak memberi peluang bagi kepala sekolah, guru dan peserta didik untuk melakukan inovasi dan improvisasi di sekolah, berkaitan dengan masalah kurikulum, pembelajaran, manajerial dan sebagainya. Ketiga, tidak diberikannya kebebasan dan kekuasaan yang besar kepada kepala sekolah beserta seperangkat tanggung jawab dalam mengelola sumber daya.

Sesuai dengan ciri-ciri sekolah sebagai organisasi yang bersifat kompleks dan unik, maka tugas dan fungsi kepala sekolah seharusnya dilihat dari berbagai sudut pandang. Dari sisi tertentu kepala sekolah dapat dipandang sebagai pejabat formal, sedang dari sisi lain dapat berperan sebagai manajer, sebagai pemimpin, sebagai pendidik dan yang tidak kalah penting seorang kepala sekolah juga berperan sebagai staf.

Kepala sekolah mempunyai peran dan fungsi yang sangat penting dalam rangka menerapkan kualitas sekolah dan sekaligus dalam manajemen peningkatan mutu pembelajaran, karena gerak langkah sebuah organisasi sekolah dikendalikan oleh seorang kepala sekolah. Mutu dalam hal ini berkaitan dengan pelatihan dan peningkatan kompetensi guru, pengadaan buku dan alat pelajaran, perbaikan sarana dan prasarana pendidikan. Namun demikian, berbagai indikator peningkatan mutu pembelajaran belum menunjukkan peningkatan yang berarti. Sebagian sekolah, terutama di kotakota menunjukkan peningkatan mutu pembelajaran yang cukup menggembirakan, namun sebagian besar lainnya masih memprihatinkan. Berbagai pihak mempertanyakan mutu pembelajaran dan apa yang kurang dari peranan kepala sekolah dalam manajemen peningkatan mutu pembelajaran. Padahal sekolah merupakan satuan pendidikan yang paling penting keberadaannya. Setiap orang mengakui bahwa tanpa menyelesaikan pendidikan, terutama pendidikan pada sekolah dasar atau yang sederajat maka secara formal seseorang tidak mungkin dapat mengikuti pendidikan di tingkat selanjutnya. Apabila didasarkan pada Peraturan Pemerintah Nomor 28 Tahun 1990, khususnya Pasal 3, paling tidak ada dua fungsi sekolah dasar. Pertama, melalui sekolah dasar anak didik dibekali kemampuan dasar. Kedua, sekolah dasar merupakan satuan pendidikan yang memberikan dasar-dasar untuk mengikuti pendidikan pada jenjang berikutnya.

Kepala sekolah di SD Negeri Sapugara Kec. Brang Rea telah memenuhi standar kepala sekolah sesuai dengan Peraturan Menteri Pendidikan Nasional No.13 Tahun 2007 (Tentang Standar Kepala Sekolah) baik kualifikasi umum maupun kualifikasi khusus serta memenuhi 5 (lima) standar kompetensi, yaitu: kompetensi kepribadian, kompetensi manajerial, kompetensi kewirausahaan, kompetensi supervisi, kompetensi sosial.

$$
\text { 99| Edisi } 2 \text { No.2 Juli } 2020
$$


Disamping itu kepala sekolah tersebut telah bekerja keras membanting tulang. Namun demikian disisi lain dari pihak para guru belum menunjukkan kinerja baik/maksimal.

\section{B. Metode Penelitian}

Penelitian merupakan ilmu yang mempelajari tentang metode-metode penelitian, ilmu tentang alat-alat dalam penelitian. Metode penelitian mengandung prosedur dan cara melaksanakan verifikasi data yang diperlukan untuk memecahkan atau menjawab masalah penelitian, peranan metodologi penelitian dalam upaya menghimpun data yang diperlukan dalam penelitian. Dari segi metodologik, penelitian ini merupakan jenis penelitian kualitatif, yakni mendeskripsikan tentang segala sesuatu yang berkaitan dengan keseluruhan pelaksanaan manajemen kepemimpinan kepala sekolah dalam meningkatkan kinerja guru di SD Negeri Sapugara Kecamatan Brang Rea. Untuk mencapai tujuan yang menghasilkan data deskriptif berupa kata-kata tertulis atau lisan dari orang-orang dan perilaku yang dapat diamati dan diarahkan pada latar dan individu tersebut secara menyeluruh.

\section{c. Temuan Penelitian}

Sebagai seorang edukator, kepala sekolah seyogyanya tetap memiliki jam mengajar. Dengan memiliki jam tatap muka dengan para siswa, sekalipun terbatas 6 jam pelajaran, cukup untuk menyelami dan memahami kondisi para siswanya. Dengan mengajar secara teratur, bukan sekadar mengisi jam kosong, kepala sekolah sebenarnya sedang memberi contoh konkrit bagi para guru yang dipimpinnya.

Berdasarkan hasil wawancara dengan kepala sekolah diperoleh informasi bahwa kepala sekolah memiliki jam mengajar sebanyak 6 jam dan beliau juga sering menggantikan mengajar ketika ada guru yang tidak masuk. Hasil pengamatan kegiatan kepala sekolah menunjukkan bahwa kepala sekolah pandai dalam mengatur waktu antara mengurus berbagai administrasi sekolah dan menemui tamu yang datang serta melaksanakan jam wajib mengajarnya.

Selain itu, hasil pengamatan terhadap kehadiran kepala sekolah di sekolah diperoleh data bahwa kepala sekolah setiap hari datang ke sekolah apabila tidak ada kegiatan dinas di luar sekolah. Jika kepala sekolah ada kegiatan dinas di luar sekolah, maka biasanya kepala sekolah mendelegasikan kepada wakil kepala sekolah untuk mengawasi dan mengontrol proses pembelajaran pada hari itu.

Kehadiran beliau juga tepat waktu sebelum bel masuk berbunyi. Bahkan kehadiran beliau seringkali lebih awal daripada kehadiran guru di sekolah. Kehadiran kepala skeolah tepat waktu di sekolah juga secara tidak langsung menjadi contoh kedisiplinan yang ditunjukkan kepala sekolah bagi para guru.

Data hasil pengamatan di lokasi penelitian pada hari Senin menunjukkan bahwa kepala sekolah sudah berada di sekolah untuk mengecek kesiapan upacara bendera yang akan dilaksanakan. Dalam

$$
\text { 100|Edisi } 2 \text { No.2 Juli } 2020
$$


pelaksanaan upacara bendera, kepala sekolah bertindak sebagai pembina upacara. Kepala sekolah juga terlihat memeriksa kelengkapan pakaian siswa sebelum mengikuti upacara bendera.

Data hasil wawancara dengan guru SD Negeri Sapugara diperoleh informasi bahwa kepala sekolah memang biasa datang lebih awal sehingga menjadikan para guru yang datang terlambat merasa malu. Guru-guru berusaha datang tepat waktu minimal tidak terlambat karena kepala sekolah biasnaya menegur jika ada guru yang terlambat datang.Kenyataan ini menunjukkan adanya konsistensi antara kenyataan dengan pernyataan kepala sekolah ketika diwawancara.

Hasil pengamatan selama dua pekan untuk mengamati kebiasaan dan disiplin kepala sekolah memperlihatkan perilaku disiplin kepala SD Negeri Sapugara kecamatan Brang Rea. Hal ini menimbulkan citra yang baik dimata guru dan staf yang dipimpinnya. Para guru pada akhirnya, juga berusaha untuk tidak terlambat. Para siswa yang memang seharusnya mendapat pelayanan pendidikan yang bermutu, telah mendapat dukungan perilaku disiplin yang ditunjukkan oleh para pendidiknya.

Hasil wawancara dengan salah seorang guru SD Negeri Sapugara diperoleh informasi bahwa pemahaman para guru terhadap kepemimpinan kepala sekolah adalah selalu berada di tempat dan transparan dalam mengelola keuangan. Hasil wawancara dengan guru juga menginformasikan bahwa guru pernah ditegur kepala sekolah karena terlambat masuk kelas. Menurut para guru yang pernah ditegur oleh kepala sekolah, cara kepala sekolah memberikan teguran juga tidak sampai menyinggung perasaan para guru. Kepala sekolah juga tidak pernah menegur guru di depan siswa. Sifat kekeluargaan nampak jelas diterapkan oleh kepala sekolah.

Berdasarkan hasil pengamatan yang dilakukan, diperoleh data bahwa pertemuan internal untuk membahas program sekolah juga dilakukan kepala sekolah bersama guru dan komite sekolah. Pola musyawarah mufakat ini juga terlihat dalam pembentukan panitia ujian dan kenaikan kelas. Hasil wawancara dengan kepala skeolah diperoleh data bahwa melalui pertemuan internal (rapat koordinasi), kepala sekolah berkesempatan memberikan pembinaan kepada para guru, membangun komunikasi dengan para guru, serta menggerakkan guru untuk mengoptimalkan proses pembelajaran di SD Negeri Sapugara, bahkan pernah mengadakan pertemuan yang sifatnya mendadak jika ada hal yang mendesak atau ada informasi penting yang harus didengar para guru.

Hasil pengamatan yang peneliti lakukan diperoleh data bahwa kepala SD Negeri Sapugara teliti dalam mengadministrasikan PBM, kesiswaan, sarana, ketenagaan, surat menyurat, dan keuangan. Informasi yang diperoleh dari hasil wawancara dengan salah guru menunjukkan bahwa kepala sekolah telah sering mengikuti pelatihan tentang administrasi sekolah. Hasil pengamatan administrasi sekolah yang peneliti lakukan menunjukkan bahwa berkas-berkas sekolah, berkas guru, dan berkas PBM cukup tertata rapi dan dapat dengan mudah ditemukan jika diperlukan. Hanya saja, sarana prasarana komputer yang masih minim menjadikan kepala sekolah dan staf kadang-

$$
\text { 101|Edisi } 2 \text { No.2 Juli } 2020
$$


kadang mengalami sedikit keterlambatan dalam mengumpulkan data yang diminta oleh pihak Dinas Pendidikan Kecamatan Brang Rea.

Mengantar para siswa dan guru menuju sebuah keberhasilan adalah satu peran penting seorang kepala sekolah. Agar proses pembelajaran berhasil perlu adanya alat kontrol yang mengukur keberhasilan yang dimaksud. Supervisi merupakan satu bentuk alat kontrol kualitas pembelajaran.

Hasil wawancara dengan guru diperoleh informasi bahwa kegiatan supervisi kelas selalu dilaksanakan terjadwal oleh kepala sekolah untuk melihat langsung proses pembelajaran yang dilaksanakan guru. Para guru tidak merasa terbebani karena kepala sekolah sudah terlebih dulu menginformasikan kegiatan supervisi sebelum pelaksanaan supervisi sehingga para guru dapat mempersiapkan diri dengan baik ketika disupervisi oleh kepala sekolah.

Berdasarkan hasil pengamatan yang peneliti lakukan selama di SD Negeri Sapugara diperoleh data bahwa prosentase keterlambatan guru datang ke sekolah sangat rendah. Selain contoh kedisiplinan yang ditunjukkan oleh kepala sekolah, sebagian besar guru rumahnya juga tidak terlalu jauh dari sekolah. Pengamatan yang peneliti lakukan terhadap perangkat pembelajaran juga melihat bahwa dalam melaksanakan proses pembelajaran di kelas, sebagian besar guru SD Negeri Sapugara membawa perangkat pembelajaran ketika melaksanakan proses pembelajaran di kelas. Selain itu, guru juga membawa buku paket atau LKS sebagai bahan ajar..

Hasil wawancara dengan guru SD Negeri Sapugara diperoleh informasi bahwa guru diwajibkan oleh kepala sekolah untuk membuat perangkat pembelajaran setiap awal tahun pelajaran baru. Menurut guru SD Negeri Sapugara, kepala sekolah memeriksa perangkat pembelajaran yang mereka kumpulkan untuk dikoreksi sebelum diarsipkan dan diperiksa oleh pengawas pembina dari Dinas Pendidikan Kecamatan Brang Rea.

Berdasarkan hasil awancara dengan guru juga diperoleh informasi bahwa kepala sekolah pernah memfasilitasi dan menyampaikan pengembangan perangkat pembelajaran bagi para guru baik secara individual maupun klasikal dalam rapat-rapat koordinasi. Data ini menunjukkan bahwa perangkat pembelajaran yang dikumpulkan oleh guru tidak hanya sebatas pelengkap administrasi saja yang diperlukan ketika pihak kepala sekolah atau pengawas menanyakan untuk keperluan supervisi atau administrasi lainnya namun sudah menjadi bagian dari kebutuhan para guru.

Mengenai pemahaman guru terhadap tujuan pembelajaran, peneliti juga melihat sebagian besar guru telah memahami tujuan pembelajaran. Beberapa orang guru yang peneliti amati, mengajar berdasarkan tujuan pembelajaran dan berbasis ketuntasan

kompetensi yang harus dicapai oleh siswa bukan semata-mata materi yang terdapat dalam bahan ajar, yakni buku dan LKS. Ini berarti, tujuan pembelajaran adalah mencapai standar kompetensi dan kompetensi dasar yang telah ditetapkan bukan hanya ketuntasan materi ajar.

Hasil pengamatan terhadap proses remedial yang menjadi hak para

$$
\text { 102|Edisiz No.2 Juli } 2020
$$


siswa menunjukkan bahwa kepala sekolah mengontrol pelaksanaan remedial yang wajib diberikan bagi siswa yang belum tuntas dalam belajar. Sebagian besar guru telah melaksanakan kegiatan remedial bagi peserta didiknya yang belum tuntas.

Hasil wawancara dengan guru SD Negeri Sapugara diperoleh informasi bahwa evaluasi hasil belajar harian atau ulangan harian, memang dibuat oleh guru masing-masing. Namun, untuk ulangan semester dibuat oleh tim dari KKG yang ditunjuk dari hasil rapat Kepala Sekolah. Peneliti mendapatkan dokumen rencana ulangan harian yang dibuat oleh guru SD Negeri Sapugara.

Berdasarkan hasil wawancara yang peneliti lakukan dengan guru SD Negeri sapugara diperoleh informasi bahwa pihak Dinas Pendidikan Kabupaten jarang mengontrol pencapaian kompetensi peserta didik dalam ulangan akhir semester, namun hanya sebatas membuat soal saja. Menurut guru SD Negeri Sapugara, sekolah juga tidak diberikan SKL atau semacam kisi-kisi soal ulangan akhir semester yang dibuat oleh Dinas pendidikan Kecamatan Brang Rea. Hal ini menjadi kendala bagi guru dalam mempersiapkan peserta didik mengikuti ulangan akhir semester. Padahal kisikisi soal tersebut sangat dibutuhkan guru mengingat kemampuan kognitif peserta didik di SD Negeri Sapugara rata-rata masih rendah.Sampai saat ini, persoalan tersebut masih menjadi kendala bagi guru-guru di SD Negeri Sapugara dalam hal mempersiapkan peserta didik menghadapi ulangan akhir semester.

\section{Pembahasan}

Dalam suatu organisasi pasti terdapat seorang pemimpin yang menjadi penanggungjawab organisasi dan yang menjadikan maju mundurnya suatu organisasi tersebut. Jadi seorang pemimpin disini sangat berperan penting terhadap kemajuan organisasi, seorang pemimpin harus pandai dalam segala bidang misalnya pandai dalam komunikasi terhadap karyawan, pandai dalam mengatasi konflik, dan lainnya. Namun demikian, dengan kompetensi disegala bidang masih banyak pemimpin(Kepala Sekolah) yang kurang berhasil dalam menjalankan organisasi sekolah tidak lain karena kelalaian dalam mengelola waktu antara melaksanakan tugas sebagai kepala sekolah dan tugas akademiknya.

Sebagai seorang guru yang diamanahkan untuk menjadi kepala sekolah, maka kepala SD Negeri Sapugara dipandang cukup baik dalam pengelolaan waktu. Ini dilihat dari temuan penelitian yang menunjukkan adanya pengelolaan waktu yang efektif dilakukan oleh kepala sekolah seperti pemilihan hari mengajar pada hari Jum'at dan Sabtu dimana pemilihan hari ini sudah memperhitungkan bahwa kegiatan di kantor Dinas Pendidikan libur kerja pada hari Sabtu sehingga hal-hal yang berkaitan dengan tugas kepala sekolah yang berhubungan dengan Dinas Pendidikan pada hari tersebut tidak ada. Ini berarti waktu kepala sekolah sepenuhnya berada di sekolah. Selain itu, kepala sekolah juga mengatur waktu menerima tamu dari luar sekolah yaitu dilayani setelah kegiatan belajar mengajar kepala sekolah selesai pada pukul

$$
\text { 103 | Edisi } 2 \text { No.2 Juli } 2020
$$


08.45 atau jam 09.00 pagi.

Dalam kaitannya dengan perencanaan pengelolaan sekolah, temuan penelitian menunjukkan bahwa kepala SD Negeri Sapugara telah memperhatikan keterlibatan guru dalam penyusunan RAPBS. Masukan dan saran yang positif dari guru dan staf didengar dan dipertimbangkan untuk dialokasikan ke dalam RAPBS yang disusun bersama. Sikap transparansi dalam hal pengelolaan keuangan sekolah juga ditunjukkan kepala sekolah sehingga tidak menimbulkan praduga negatif di kalangan guru dan orang tua peserta didik mengenai keuangan sekolah.

Dalam mengelola tenaga pendidikan, salah satu tugas penting yang guru untuk melaksanakan kegiatan pengembangan profesi melalui berbagai kegiatan pendidikan dan pelatihan, baik yang dilaksanakan sekolah, seperti: KKG (tingkat sekolah), workshop, in house training, diskusi profesional dan sebagainya, atau melalui kegiatan pendidikan dan pelatihan di luar sekolah, seperti: kesempatan melanjutkan pendidikan atau mengikuti berbagai kegiatan pelatihan yang diselenggarakan pihak lain. Temuan penelitian memperlihatkan bahwa kegiatan pengembangan profesi guru yang dilakukan kepala sekolah masih terbatas di lingkungan sekolah...

Kepala SD Negeri Sapugara selaku manajer mempunyai peranan penting dalam mengembangkan mutu pendidikan di SD Negeri Sapugara. Sebagai manajer, kepala sekolah telah mempertimbangkan peran penting yang tidak hanya membuat pengaruh tetapi ia membina bawahan agar memiliki kemampuan dalam mengatur kinerjanya baik kemampuan manajerial maupun kemampuan teknis. Karena itulah, para manajer di tuntut untuk memiliki pandangan dan strategi jangka panjang ke arah mana organisasi akan diarahkan.Dalam pelaksanaan program-program sekolah harus didukung oleh kemampuan manajerial kepala sekolah yang demokratis dan profesional. Kepala sekolah dan guru-guru sebagai tenaga pelaksanaan inti program sekolah merupakan orang-orang yang memiliki kemampuan dan integritas profesional.

Temuan penelitian memperlihatkan bahwa dalam rangka melakukan peran dan fungsinya sebagai manajer, kepala sekolah SD Negeri Sapugara telah memiliki strategi yang tepat untuk memberdayakan segala sumber daya sekolah untuk mencapai tujuan pendidikan meskipun dari sarana dan prasarana masih minim dibandingkan sekolah-sekolah di sekitarnya. Namun demikian, kemampuan manajerial kepala SD Negeri Sapugara sudah cukup baik dalam mengkoordinasikan, menggerakkan, dan menserasikan segala sumber daya yang ada pada satuan pendidikan yang dipimpinnya untuk mencapai tujuan bersama.

Pada dasarnya kemampuan manajerial sangat terkait dengan bagaimana penerapan fungsi-fungsi manajemen atau proses manajemen, yaitu perencanaan, pengorganisasian, pelaksanaan, pengontrolan, dan evaluasi. Kepala sekolah adalah manajer pendidikan tingkat sekolah dan ujung tombak utama dalam mengelola pendidikan level sekolah. Tanggung jawab yang harus diembannya adalah kepala sekolah harus memiliki kemampuan dalam melaksanakan tugas kepemimpinananya dengan baik yang diwujudkan dalam kemampuan menyusun program sekolah, organisasi personalia,

$$
\text { 104| Edisi } 2 \text { No.2 Juli } 2020
$$


memberdayakan tenaga kependidikan, dan mendayagunakan sumberdaya sekolah secara optimal.

Temuan penelitian menunjukkan bahwa dilihat dari aspek kepribadian, kepemimpinan kepala SD Negeri Sapugara telah berhasil menjadi teladan bagi guru dan siswa. Keteladanan ini dapat dilihat dari sikap disiplin yang diterapkan kepala sekolah serta pola komunikasi yang dibangun dan dikembangkan di sekolah. Kepala SD Negeri Sapugara memberikan keteladanan dalam hal kehadiran di sekolah. Beliau berusaha menjadi orang pertama yang hadir di sekolah. Hal ini ternyata memudahkan kepala SD Negeri Sapugara dalam mengontrol kedisiplinan guru dalam melayani para peserta didik.

Selanjutnya, berdasarkan temuan penelitian tentang kinerja guru SD Negeri Sapugara Kesamatan Brang Rea dapat diidentifikasi karakteristik kinerjanya sebagai berikut: (1) prosentase keterlambatan guru datang ke sekolah sangat rendah. Selain contoh kedisiplinan yang ditunjukkan oleh kepala sekolah, sebagian besar guru rumahnya juga tidak terlalu jauh dari sekolah, (2) guru telah membuat perangkat pembelajaran di awal tahun pelajaran sebagai tugas administrasi, (3) dalam melaksanakan proses pembelajaran di kelas, sebagian besar guru SD Negeri Sapugara membawa perangkat pembelajaran ketika melaksanakan proses pembelajaran di kelas, (4) melaksanakan proses pembelajaran yang mendidik bagi peserta didik, dan (5) melaksanakan evaluasi yang sesuai dengan tujuan pembelajaran.

Karakteristik kinerja yang ditunjukkan guru SD Negeri Sapugara menurut peneliti sudah cukup baik dalam mendukung pencapaian tujuan sekolah. Kinerja yang ditunjukkan guru dapat diamati dan diukur keberhasilannya oleh kepala sekolah dan guru itu sendiri. Ini sejalan dengan pengertian kinerja yang diungkapkan oleh Campbell dan Richard dalam (Sudarmanto, 2009:9) menyatakan bahwa "Kinerja adalah sesuatu yang secara aktual orang kerjakan dan dapat diobservasi". Dalam pengertian ini, kinerja mencakup tindakantindakan dan perilaku yang relevan dengan tujuan organisasi. Pengertian kinerja atau prestasi kerja adalah merupakan hasil kerja seseorang secara kualitas dalam melaksanakan tugas-tugasnya sesuai dengan tanggung jawab yang diberikan kepada orang tersebut. Kinerja adalah merupakan suatu kemampuan kerja atau prestasi kerja yang diperlihatkan oleh seorang pegawai untuk memperoleh hasil kerja yang optimal.

Kinerja mengajar guru berkaitan dengan tugas perencanaan, pengelolalan pembelajaran dan penilaian hasil belajar siswa. Temuan penelitian memperlihatkan bahwa ada upaya para guru di SD Negeri Sapugara untuk meningkatkankompetensi profesionalnya. Contoh konkrit yang ada, pada tahun yang lalu nilai ujian nasional pada bidang studi matematika yang diraih peserta didik SD Negeri Sapugara dapat bersaing dengan siswa SD favorit yang ada di Kecamatan Brang Rea. Berkat usaha keras dan bimbingan guru matematikadan semangat para peserta didik untuk belajar dengan giat, maka hasil ujian cukup memuaskan.

Faktor pendukung cukup baiknya kinerja guru adalah fungsi kontrol dari kepala sekolah terhadap kinerja guru. Mulai dari usaha mengontrol perangkat atau perencanaan pembelajaran, mengontrol pelaksanaan pembelajaran, dan

$$
\text { 105|Edisi } 2 \text { No.2 Juli } 2020
$$


mengontrol evaluasi pembelajaran yang dilakukan oleh guru.Kinerja merefleksikan kesuksesan suatu organisasi, maka dipandang penting untuk mengukur karakteristik tenaga kerjanya. Kinerja guru merupakan kulminasi dari tiga elemen berkaitan yakni keterampilan, upaya sifat keadaan dan kondisi eksternal. Kinerja individu merupakan hasil kerja baik dari segi kualitas dan kuantitas berdasarkan standar kerja yang telah ditentukan.Kinerja individu tercapai jika didukung atribut individu, upaya kerja, dan dukungan organisasi.

\section{E. Kesimpulan}

Berdasarkan pemaparan data temuan penelitian dapat disimpulkan bahwa kepemimpinan kepala sekolah dalam upaya meningkatkan kinerja guru melaksanakan pembelajaran di SD Negeri Sapugara Kecamatan Brang Rea tidak mengalami hambatan yang berarti dan dapat dikelola dengan baik.Selanjutnya dapat dipaparkan beberapa kesimpulan khusus, sebagai berikut: (1) Kepemimpinan kepala sekolah dalam upaya meningkatkan kinerja guru melaksanakan pembelajaran di SD Negeri Sapugara Kecamatan Brang Rea telah dilaksanakan cukup baik meskipun belum ditunjang dengan fasilitas yang lengkap terutama dalam mengelola waktu antara melaksanakan tugas tambahan sebagai kepala sekolah serta melaksanakan tugas akademik sebagai guru. Selain itu, pendekatan kepemimpinan situasional diterapkan melalui aspek kepribadian yang baik dan pembinaan disiplin kerja serta pengembangan pola komunikasi efektif di kalangan warga sekolah, (2) Kinerja guru dalam melaksanakan pembelajaran di SD Negeri Sapugara sudah cukup baik. Hal ini ditandai dengan tanggungjawab dan disiplin yang tinggi dalam melaksanakan tugas mengajar, melaksanakan pembelajaran dan pembinaan yang mendidik bagi peserta didik, serta menerima hasil supervisi untuk peningkatan kompetensi dan perbaikan kinerja, dan (3) Upaya kepala sekolah dalam meningkatkan kinerja guru dalam melaksanakan pembelajaran di SD Negeri Sapugara dilakukan antara lain melalui beberapa kegiatan yaitu: a) melaksanakan penilaian kinerja guru, b) melaksanakan supervisi akademik pembelajaran yang dilaksanakan guru di kelas, c) melaksanakan tindak lanjut hasil supervisi. 


\section{Daftar Rujukan}

Arifin, Psikologi Dakwah, Suatu Pengantar Studi, (Jakarta: Bumi Aksara, 2000). Arikunto, Suharsimi, Prosedur Penelitian Suatu Pendekatan Praktek, Cet 12 (Jakarta: Rineka Cipta, 2004).

Bafadal, Ibrahim, Manajemen Peningkatan Mutu Sekolah Dasar dari Sentralisasi Menuju Desentralisasi, (Jakarta: Bumi Aksara, 2006).

Bukhari, Al-Imam Abu Abdillah Muhammad ibn Ismail ibn al-Mugirah ibn Bardizbah, Sahih al-Bukhari, Juz. 3, (Beirut Libanon: Dar al-Fikr, 1410 $\mathrm{H} / 1990 \mathrm{M})$.

DEPDIKNAS. Kamus Besar Bahasa Indonesia, (Jakarta: Balai Pustaka, 2002).

al-Dimasyqî, Ismâ'îl ibn Kasîr al-Qurasyî, Tafsîr al-Qur'an al-Azîm., juz 3, (Beirut: Dâr al-Ma'rifah, 1978)

Effendy, Onong Uchjana, Psikologi Manajemen, (Bandung: Alumni, 1985). Faizah dan Lalu Muchsin Effendi, Psikologi Dakwah, (Jakarta: Kencana, 2006). Gerungan, W.A., Psikologi Sosial, (Bandung: PT.al-Maarif, 1978).

Hadi, Sutrisno, Metodologi Research, Jilid I (Yogyakarta: Andi Offset, 2001). Cet. 32.

Joewono, Heri, Pokok-Pokok Kepemimpinan Abad 21, (Jakarta: Balai Pustaka 2002).

Karjadi. Kepemimpinan (Leadership), (Bogor: Politeia, 1981).

Manullang, M., Dasar-Dasar Manajemen, (Jakarta: Balai Aksara, 1963). Mar'at, Pemimpin dan Kepemimpinan, (Bandung: Ghalia Indonesia, 1983). Margono, S., Metodologi Penelitian Pendidikan, (Jakarta: Rineka Cipta, 2000). Moekiyat, Kamus Management, (Bandung: Alumni, 1980).

Moleong, Lexy J., Metodologi Penelitian Kualitatif, (Bandung: Remaja Rosdakarya, 2000).

Campbell dan Richard dalam (Sudarmanto, 2009:9)

Muhajir, Noeng, Metodologi Penelitian Kualitatif, (Yogyakarta: Rake Sarasin, 2000).

Mulyasa, E., Manajemen Berbasis Sekolah, Konsep. Strategi dan Implementasi, (Bandung: remaja Rosdakarya, 2007).

, Menjadi Kepala Sekolah Profesional dalam Konteks Menyukseskan MBS dan KBK, (Bandung: Remaja Rosdakarya, 2003).

Mulyono, Manajemen Administrasi dan Organisasi Pendidikan, (Yogyakarta: ArRuzz Media, 2008).

Purwanto, Ngalim, Administrasi dan Supervisi Pendidikan, (Bandung: PT Remaja Rosdakarya, 2002).

Purwadarminta, WJS., Kamus Umum Bahasa Indonesia, (Jakarta: Balai Pustaka, 1982).

Shaleh, A.Rosyad, Management Da'wah Islam, (Jakarta: Bulan Bintang, 1976).

Siagian, Harbangan, Manajemen Suatu Pengantar, (Semarang: Satya Wacana. 1993).

Siagian, Sondang P., Filsafat Administrasi. (Jakarta: Gunung Agung, 1984). Soenarjo, Al-Qur'an dan Terjemahnya, (Semarang: Toha Putra, 1993).

Sudjana, Nana dan Ibrahim, Penelitian dan Penilaian Pendidikan, (Bandung:

$$
\text { 107| Edisi } 2 \text { No.2 Juli } 2020
$$


Sinar Baru, 1989).

Terry, George R., Principles of Management, (Richard D. Irwan, INC. Homewood, Irwm-Dorsey Limited Georgetown, Ontario L7G 4B3, 1977).

Thoha, Miftah, Kepemimpinan dalam Manajemen, (Jakarta: Raja frafindo Persada, 1995).

Tim Penyusun Kamus Pusat Pembinaan dan Pengembangan Bahasa Departemen Pendidikan dan Kebudayaan, Kamus Besar Bahasa Indonesia, (Jakarta: Balai Pustaka, 1998).

Wahjosumidjo, Kepemimpinan Kepala Sekolah Tinjauan Teoritik dan Permasalahannya, (Jakarta: Raja Grafindo Persada, 2008).

Zainuddin, Muhadi, dan Abd. Mustaqim, Studi Kepemimpinan Islam Telaah Normatif \& Historis, (Semarang: Putra Mediatama Press, 2005). 